\title{
Data centers environmental impact assessment features
}

\author{
Andrey Semenov ${ }^{1, *}$, and Ekaterina Oganesyan ${ }^{2, \dagger}$ \\ ${ }^{1}$ Moscow State University of Civil Engineering (MGSU) National Research University, Moscow, \\ Russia \\ ${ }^{2}$ Mendeleev University of Chemical Technology of Russia, Moscow, Russia
}

\begin{abstract}
Data centers became significant sources of environmental impact: each year global data centers consume TWh of electricity, generate comparable thermal emissions to the atmosphere and/or hydrosphere, create wastes of electronic equipment and life-expired batteries, and create other types of direct and indirect ecological footprint. In conformity with the sustainable development concept data centers environmental impact of all types should be numerically assessed to compare to the environmental capacity and move towards sustainability. It requires ecological footprint (carbon footprint in particular) to be assessed. Existing xUE Effectiveness Metrics used for data centers are all relative, so data centers' environmental impact cannot be calculated directly from it. Methods of payment calculation for negative environmental impact, used in Russia, do not take into account data center features and can hardly be used for the assessment tasks. Data centers need to adapt existing and develop new assessment methods for its environmental impact, considering all the resources consumed and all the emissions generated.
\end{abstract}

\section{Introduction}

Data centers consume large amounts of electricity. Sources may differ in their estimates: according to [1] datacenter annual global electricity consumption in 2010-2018 increased from 194 TWh to $205 \mathrm{TWh}$, while [2] states that it already achieved $286 \mathrm{TWh}$ in 2016. However, sources agree that datacenter consumption is hundreds of TWh per year, which is $1-1.5 \%$ of total world electricity production. There is a trend to growth of datacenter energy consumption, and one of the reasons is data centers number increase caused by the ICT development in general and the Internet of Things spreading in particular. Thus, the largest Russian data center (Rostelecom, Udomlya) with its $1^{\text {st }}$ stage of 40 MW power consume $0.65 \mathrm{TWh}$ annually. Total number of data centers increases all over the world including Russia; new facilities appear and some existing facilities expand. Based on existing trends [2] forecasts world datacenter consumption will achieve $321 \mathrm{TWh} /$ year by 2030.

The major part of the electricity consumed by data centers converts to thermal energy and comes to the environment: to the atmosphere when using air cooling, to the atmosphere

\footnotetext{
* Corresponding author: SemenovAB@mgsu.ru
} 
and/or the hydrosphere when using liquid cooling systems [3]. In addition to thermal environmental pollution directly generated by data centers, these facilities are responsible for emissions occurring at electricity generating plants, energy from which is then consumed by data centers. As carbon quota develops, this aspect should be estimated and taken under control.

In case of centralized energy supply failure data centers use backup power supplies, which also have an environmental impact. Diesel generators able to power datacenter facilities have the output comparable to the same MW data center power, which means dozens tons of diesel fuel consumed per day. Hydrocarbon fuel combustion results in direct $\mathrm{CO}_{2}$ emissions. Also some less significant emissions of carbon monoxide, nitrogen oxides, unburned hydrocarbons etc. take place.

In case of cooling agent leakage or fire extinguishing system activation liquid, gaseous and solid (powder) emissions/wastes can take place. Some of them are considered pollutants. Depending on systems used these can be: ethylene glycol, "waterless water/dry water" organic compounds (fluorinated ketones), halocarbons (CFCs, HFCs) etc. In case of carbon dioxide fire extinguishing system activation direct emission of $\mathrm{CO}_{2}$ takes place.

Data centers also create solid wastes: electronic equipment (out of order or obsolete), storage media (including deliberately destroyed to keep confidentiality of information, although their lifetime has not expired yet), and life-expired/lost capacity batteries.

Sustainable development principles applied to data centers functioning mean that all the forms of datacenter environmental impact must be numerically assessed to compare it to environment capacity. Meanwhile numerical criteria data centers currently use do not correspond to this task, despite the fact some of them are called Sustainability Metrics [4$5]$.

\section{Materials and methods}

PUE (Power Usage Effectiveness) metric offered by The Green Grid [6] in 2007 is widely used to assess data center efficiency. Initially it was calculated as follows:

$$
\text { PUE }=\text { Total Facility Power / IT Equipment Power }
$$

Later sources [7] use corrected formula:

$$
\begin{aligned}
& \text { PUE = Total Facility Energy / IT Equipment Energy = } \\
& =1+\text { Non IT Facility Energy / IT Equipment Energy }
\end{aligned}
$$

Created to assess the efficiency of datacenter energy consumption, PUE assumes the closer is the metric to 1 the greater is the share of energy consumed by the target IT equipment (and the less by the auxiliary engineering subsystems). But neither the initial nor the corrected PUE metric report anything on the energy consumption absolute value and the associated environmental impact. All PUE metrics are relative. By the time the PUE was proposed, the ecological footprint and carbon footprint terms had already been developed. But none of them can be calculated or assessed from the PUE metric as it is.

Different data centers calculate PUE in different ways, excluding some engineering subsystems from consideration, which leaves a wide field for manipulation [8]. For example, the numerator may exclude the energy consumed by cooling systems (which is comparable to the IT equipment consumption itself) if the data center "receives cold" from an external supplier. The denominator can be artificially inflated by indicating the consumption declared in the IT equipment specifications instead of the actual consumption. Such manipulations make it difficult to compare different data centers to each other, thus 
PUE cannot be used for practical purposes and cannot serve as a basis for sustainable development implementation [9-10].

WUE (Water Usage Effectiveness) and CUE (Carbon Usage Effectiveness) metrics offered by The Green Grid in 2010 are intended to assess respectively the efficiency of the water use and carbon fuel use in data centers [4-5]. But these as well as other xUE ( $X$ Usage Effectiveness) metrics are relative, all based on the ratio of the water consumed per year, carbon dioxide emissions per year and other material flows attributable to the entire facility, to the IT equipment energy consumption:

$$
\begin{gathered}
W U E=\text { Annual Water Usage / IT Equipment Energy } \\
C U E=\text { Total } \mathrm{CO}_{2} \text { emissions caused by Total Data Center Energy / } \\
/ \text { IT Equipment Energy }
\end{gathered}
$$

Despite the units these metrics use $-1 / \mathrm{kWh}$ for WUE and $\mathrm{kg}$ or $\mathrm{g}$ of $\mathrm{CO}_{2} \mathrm{kWh}$ for CUE - none of them contain the information on the material and energy resources consumed by the data center. So these metrics cannot be used to assess datacenter environmental impact. At the same time it should be mentioned that WUE and CUE formulas include coefficients that characterize the sources of energy consumed by the data center:

- EWIF (Energy Water Intensity Factor), 1/kWh, depends on the energy generation facility, which can be own (situated on the datacenter site) or external (owned by thirdparty suppliers);

- CEF (Carbon Emission Factor), kg or $\mathrm{g}$ of $\mathrm{CO}_{2} \mathrm{kWh}$, depends on carbon fuel used for energy generation.

$$
\begin{aligned}
& W U E_{\text {source }}=(\text { Annual Source Energy Water Usage + Annual Site Water Usage }) \text { / } \\
& \quad \text { /IT Equipment Energy }= \\
& =E W I F \times \text { PUE + Annual Site Water Usage / IT Equipment Energy } \\
& \qquad U E=C E F \times P U E
\end{aligned}
$$

\begin{tabular}{|c|c|}
\hline Fuel & $\mathrm{CEF}, \mathrm{kg}$ of $\mathrm{CO}_{2} / \mathrm{kWh}$ (IPCC data) \\
\hline Coal & 0.863 to 0.941 \\
\hline Brown coal & up to 1.175 \\
\hline Petroleum & 0.893 \\
\hline \multirow[t]{2}{*}{ Natural gas } & $\begin{array}{c}0.491 \text { to } 0.891 \text { depending on generation } \\
\text { technology }\end{array}$ \\
\hline & $\begin{array}{c}\text { CEF, } \mathbf{k g} \text { of } \mathbf{C O}_{2} / \mathbf{k W h} \\
\text { (IPCC and EPA data, Russian sources, } \\
\text { and authors' own estimates) }\end{array}$ \\
\hline $\begin{array}{l}\text { Unknown source, } \\
\text { average }\end{array}$ & $0.59-0.8$ \\
\hline
\end{tabular}

If data centers will regularly collect and publish data on the energy sources used and the amount of resources consumed, then EWIF and CEF factors will allow calculating the actual emissions and assessing datacenter environmental impact.

Table 1. $\mathrm{CO}_{2}$ emissions per $\mathrm{kWh}$ of energy obtained from carbon fuel combustion.

Recent years the estimates or carbon dioxide emissions associated with hydropower have been revised upward, from close to zero to dozens of grams of $\mathrm{CO}_{2}$ per $1 \mathrm{kWh}$. The most reasonable estimate for today is made by Chinese authors [11]: $0.092 \mathrm{~kg}$ of $\mathrm{CO}_{2} / \mathrm{kWh}$. One can expect that detailed scientific analysis will change values currently assumed by 
International Energy Agency for nuclear power as $0.004-0.012 \mathrm{~kg}$ of $\mathrm{CO}_{2}$ per $1 \mathrm{kWh}$, to higher values.

Table 2. Water consumption per kWh of energy obtained from different sources.

\begin{tabular}{|c|c|c|}
\hline $\begin{array}{c}\text { Method used for } \\
\text { electricity } \\
\text { generation }\end{array}$ & $\begin{array}{c}\text { EWIF, } \mathbf{h W h} \\
\text { (The Green Greed } \\
\text { recommendations) }\end{array}$ & Note \\
\hline Hydropower & 0 & $\begin{array}{c}\text { Water is used for electricity } \\
\text { generation but not consumed; } \\
\text { all the water is available for } \\
\text { future consumption }\end{array}$ \\
\hline Coal combustion & 2.2 to 2.8 & \\
\hline Nuclear power & 3.3 & \\
\hline $\begin{array}{c}\text { Natural gas } \\
\text { combustion }\end{array}$ & 0.8 & \\
\hline
\end{tabular}

When generating electricity locally at the data center site, emissions to the environment can be estimated based on the amount of fuel consumed.

Table 3. $\mathrm{CO}_{2}$ emissions per carbon fuel unit.

\begin{tabular}{|c|c|c|}
\hline Fuel & $\begin{array}{c}\text { Specific carbon } \\
\text { footprint } \\
\text { (EPA and IPCC data, } \\
\text { other international } \\
\text { sources) }\end{array}$ & $\begin{array}{c}\text { Specific carbon } \\
\text { footprint } \\
\text { (Russian sources } \\
\text { and authors' own } \\
\text { estimates) }\end{array}$ \\
\hline $\begin{array}{c}\text { High-octane } \\
\text { gasoline }\end{array}$ & 1.93 to $2.35 \mathrm{~kg}$ of CO$/ 1$ & $2.39 \mathrm{~kg} \mathrm{of} \mathrm{CO} / 1$ \\
\hline Diesel fuel & 2.64 to $2.69 \mathrm{~kg}$ of $\mathrm{CO}_{2} / 1$ & $2.69 \mathrm{~kg}$ of $\mathrm{CO}_{2} / \mathrm{l}$ \\
\hline Natural gas & $\begin{array}{c}1.90 \text { to } 1.94 \mathrm{~kg} \text { of } \\
\mathrm{CO}_{2} / \mathrm{m}^{3}\end{array}$ & $1.98 \mathrm{~kg}$ of $\mathrm{CO}_{2} / \mathrm{m}^{3}$ \\
\hline
\end{tabular}

Main resources for typical data center, its emissions and wastes are shown in Figure 1 as input and output flows. 


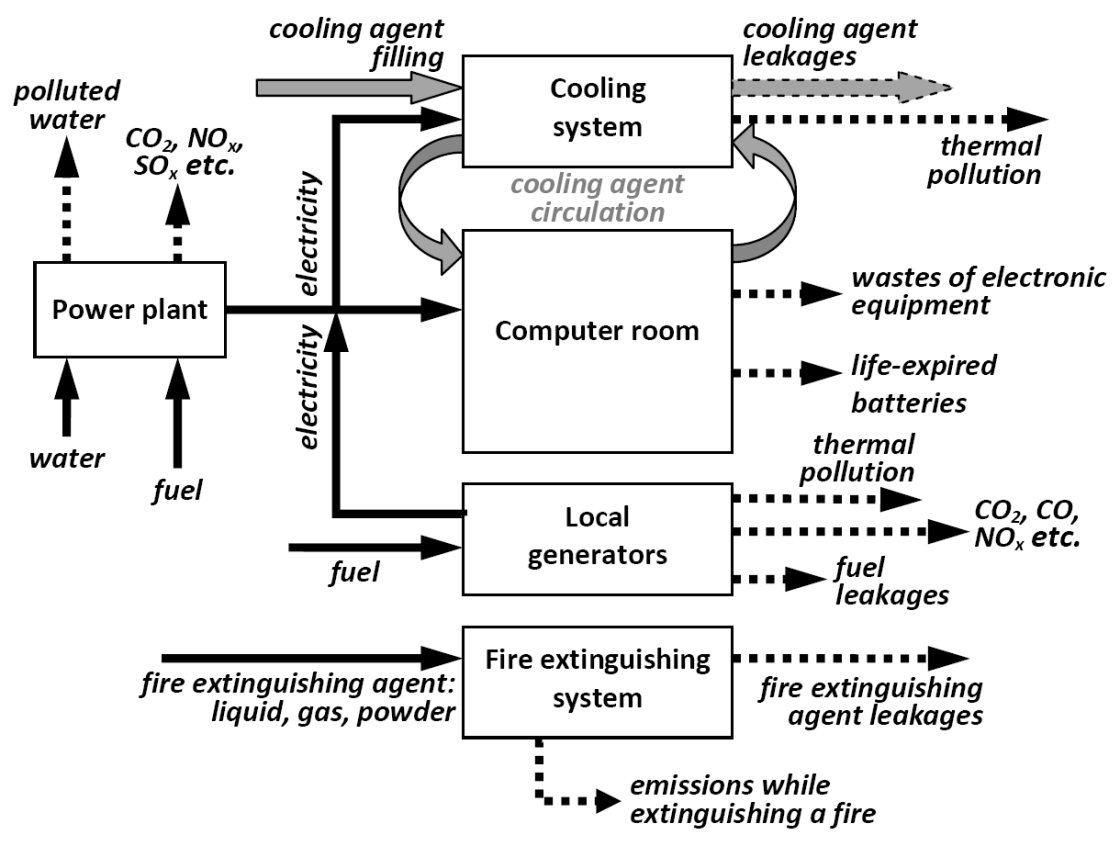

Fig. 1. Data center main resources, emissions and wastes.

Some of material/energy flows and environmental impacts shown in Figure 1 can be estimated by existing methods as shown below.

\subsection{Numerical assessment for some types of datacenter environmental impacts}

Taking into account different data centers sizes as well as the modular design used for medium and large facilities, it is advisable to perform the assessment per 1 module, which has a certain degree of autonomy: a separate computer room; dedicated cooling and fire extinguishing systems; UPS system based on electrochemical power source etc. The use of local generators can also be assessed per 1 datacenter module. A typical module size of 200 racks with $5 \mathrm{~kW}$ power per rack corresponds to total power of $1 \mathrm{MW}$. The assessment for sites of a different size and power can be performed proportionally.

\subsubsection{Environmental impact as a result of electricity consumption obtained from external sources as well from local generation}

1 MW datacenter module consumes $8.76 \mathrm{GWh}$ of electricity annually. Current carbon footprint concept assumes that carbon dioxide emissions associated with the electricity consumed are the responsibility of the consumer. If we know the type of power plant delivering the energy to the data center, we can estimate $\mathrm{CO}_{2}$ emissions in accordance with Table 1. If the source is unknown, the annual emissions can vary from 5,168.4 to $7,008 \mathrm{t}$ $\mathrm{CO}_{2}$ per $1 \mathrm{MW}$ of datacenter power.

Current payment rates in Russian Federation for pollutants emission into the atmosphere from stationary sources [12] and calculation methods applied do not consider carbon dioxide as an environmental pollutant. A carbon quota and carbon footprint payment system has yet to be developed, both internationally and locally. 
As noted before, the major part of the electricity consumed by data centers converts to thermal energy and comes to the atmosphere and/or the hydrosphere. Despite the datacenters heat emission of dozens and hundreds GWh per year, current methods to assess the environmental impact of industrial facilities in Russian Federation do not take heat emissions into account and do not consider necessary any payments for thermal pollution. Payment rates development can base on the ratio of $8.76 \mathrm{GWh} /$ year of thermal emission per each $1 \mathrm{MW}$ of datacenter power.

In addition to $\mathrm{CO}_{2}$ emission power plants of different types can be responsible for $\mathrm{NOx} / \mathrm{SOx}$ oxides and other pollutants emissions, as well as for certain water consumption. However, the responsibility for such types of environmental impact, unlike the carbon footprint, is not shifted to the consumer. Energy facilities of the Russian Federation make regular payments to the budget in accordance with the payment rates for negative environmental impact [12].

The calculation methods used for energy facilities can be applied to a certain extent to local datacenter electricity generation processes. Payment rates list for pollutants emission to the atmosphere from stationary sources includes some substances contained in the exhaust gases of diesel generators and other generating units (see Table 4). Calculations are made in rubles per 1 ton of pollutants, and the rates are set each year by corresponding Governmental Regulation. Thus, in 2021 one should use payment rates set for 2018 by a factor of 1.08 .

The amount of such pollutants emission per unit of fuel consumed can be estimated based on the specific generating equipment data sheets.

Table 4. Payment rates for pollutants emission to the atmosphere from stationary sources [12].

\begin{tabular}{|c|c|c|c|}
\hline \multirow{2}{*}{ Pollutant } & \multicolumn{3}{|c|}{$\begin{array}{c}\text { Payment rates per 1 ton of pollutant (Russian } \\
\text { Federation rubles) }\end{array}$} \\
\cline { 2 - 4 } & $\mathbf{2 0 1 6}$ & $\mathbf{2 0 1 7}$ & $\mathbf{2 0 1 8}$ \\
\hline $\begin{array}{c}\text { Nitrogen } \\
\text { dioxide }\end{array}$ & 133.1 & 138.8 & 138.8 \\
\hline Nitrogen oxide & 89.6 & 93.5 & 93.5 \\
\hline $\begin{array}{c}\text { Carbon } \\
\text { monoxide }\end{array}$ & 1.5 & 1.6 & 1.6 \\
\hline etc. & $\ldots$ & $\ldots$ & $\ldots$ \\
\hline
\end{tabular}

Payments taken in past for diesel and other fuels emission to the environment, for emission of unburned hydrocarbons were canceled in Russian Federation due to the use of an excise tax on automobile and diesel fuel, to avoid double payments for negative environmental impact. In fact any data center pays for such an impact at the time of diesel fuel purchase, but it is still necessary to track these emissions in order to plan actions to reduce the environmental impact whatever it is $[13,14]$.

Based on the average technical specifications for 1000 to $5000 \mathrm{~kW}$ diesel generator units, about $280 \mathrm{l} / \mathrm{h}$ of diesel fuel is required to support $1 \mathrm{MW}$ target equipment operation, which leads to $0.75 \mathrm{t}$ of $\mathrm{CO}_{2} / \mathrm{h}$ emission. Local generation is intended to provide electricity supply in case of emergency and failure of external electricity supplies. Such periods can hardly exceed several hours a year.

Thermal pollution can be estimated through the diesel fuel specific heat of combustion, which is $42.7 \mathrm{MJ} / \mathrm{kg}$ : most of the energy will convert directly to thermal form at electricity generation stage; the rest will do the same after the generated electricity is used by data center IT equipment and auxiliary engineering systems. When using diesel generators, 2.8 MWh of low-grade thermal energy will be emitted to the environment every hour per each $1 \mathrm{MW}$ of datacenter power. 


\subsubsection{Environmental impact as a result of cooling and fire extinguishing agents' leakages}

Payment rates [12] for pollutants emission to the atmosphere and discharge to natural water bodies mention only some of the substances used in the data center, which can be subject to leakages during normal operation and emissions in case of failure or fire: ethylene glycol, some freons, the simplest ketones etc. The rates do not list: fluorinated ketones (which include "dry water" Novec 1230), some HFCs/halons and other organic substances used as fire extinguishing agents, powder/aerosol fire extinguishing agents. Payment rates for such substances emission to the environment should be developed in future.

Taking into account the reserve cooling agent containers capacity in datacenter modules, possible leakage/emissions can hardly exceed $30 \mathrm{~m}^{3}(20-30 \mathrm{t}$ depending on agent density) per 1 datacenter module for liquids and an equivalent mass for agents converting to gas.

Gas agent emission in case of extinguishing a fire in a datacenter module can be determined through an average normative volume fire extinguishing concentration $\sim 10 \%$. 200 racks datacenter module of $600 \mathrm{~m}^{2}$ average area and $6 \mathrm{~m}$ ceiling height will require more than $360 \mathrm{~m}^{3}$ of gas fire extinguishing agent.

Noble gases, nitrogen, their mixtures (argonite, etc.) are not considered as environmental pollutants regardless the size of emission. In case carbon dioxide is used as a fire extinguishing agent or forms a part of a mixture (e.g. inergen), this must be taken into account as a direct $\mathrm{CO}_{2}$ emission to the environment. Emissions can reach $0.72 \mathrm{t}$ of $\mathrm{CO}_{2}$ per extinguishing a fire in 1 datacenter module. In case of CFCs/HFCs fire extinguishing agents not only payment rates for emission to the environment must be used, but also the probable ozone depleting effect must be taken into account.

\subsubsection{Wastes of electronic equipment and life-expired electrochemical power sources (batteries)}

Average 5-10 year lifetime of electronic IT equipment, servers, storage systems, battery UPS systems and the batteries themselves means annual depreciation of $20-10 \%$ respectively. Thus solid waste flows can be estimates in t/year per 1 datacenter module. Datacenter $45 \mathrm{U}$ racks average filling with $15 \mathrm{~kg} / \mathrm{U}$ IT equipment means $6.8-13.5 \mathrm{t}$ of electronic equipment become out of operation each year. The existing payment rates for solid wastes disposal [12] classify electronic boards as Hazard class IV (low hazard) wastes.

Table 5. Payment rates for wastes disposal [12].

\begin{tabular}{|c|c|c|c|}
\hline \multirow{2}{*}{ Waste types } & \multicolumn{3}{|c|}{$\begin{array}{c}\text { Payment rates per 1 ton of wastes } \\
\text { (Russian Federation rubles) }\end{array}$} \\
\cline { 2 - 4 } & $\mathbf{2 0 1 6}$ & $\mathbf{2 0 1 7}$ & $\mathbf{2 0 1 8}$ \\
\hline $\begin{array}{c}\text { Hazard class I of wastes } \\
\text { (extreme hazard) }\end{array}$ & 4452,4 & 4643,7 & 4643,7 \\
\hline $\begin{array}{c}\text { Hazard class II of wastes } \\
\text { (high hazard) }\end{array}$ & 1908,2 & 1990,2 & 1990,2 \\
\hline $\begin{array}{c}\text { Hazard class III of } \\
\text { wastes } \\
\text { (moderate hazard) }\end{array}$ & 1272,3 & 1327 & 1327 \\
\hline $\begin{array}{c}\text { Hazard class IV of } \\
\text { wastes } \\
\text { (low hazard) }\end{array}$ & 635,9 & 663,2 & 663,2 \\
\hline \multicolumn{2}{|c|}{} & & \\
\hline
\end{tabular}


Batteries, depending on their type, are classified as Hazard class II or III wastes. With the average weight of $18 \mathrm{~kg} / \mathrm{kW}$ for battery equipped UPS systems (based on data sheets), able to maintain the equipment operation for several minutes required for local generators to start and reach a stable operating mode, the laden weight of the UPS system can be determined per $1 \mathrm{MW}$ of datacenter power: $18 \mathrm{t}$. Thus the weight of out of operation equipment can be $1.8-3.6 \mathrm{t} /$ year.

Electronic equipment and batteries recycling is currently at an early development stage. The processing is energy intensive, implies the use of large amounts of acids and other substances. On the one hand, the recycling can reduce datacenter operation ecological footprint and turn the solid wastes to raw materials for processing plants. On the other hand, the economic and resource benefits of precious and rare metals extraction from electronic wastes can be accompanied by a significant negative environmental impact from the processing enterprises themselves, which should be the subject of further study and assessment.

\section{Results and discussion}

The assessment results are shown in Table 6 .

Table 6. Assessment results for datacenter environmental impacts.

\begin{tabular}{|c|c|c|c|c|c|}
\hline \multirow[b]{2}{*}{$\begin{array}{c}\text { Impact } \\
\text { originator }\end{array}$} & \multicolumn{5}{|c|}{ Impact magnitude } \\
\hline & $\begin{array}{l}\text { Carbon } \\
\text { footprint } \\
\text { or wastes }\end{array}$ & $\begin{array}{l}\text { Thermal } \\
\text { emission }\end{array}$ & \begin{tabular}{|c}
${\mathrm{Non} \mathrm{CO}_{2}}$ \\
emission to \\
the \\
atmosphere
\end{tabular} & $\begin{array}{c}\text { Discharge } \\
\text { to natural } \\
\text { water } \\
\text { bodies }\end{array}$ & $\begin{array}{c}\text { Solid } \\
\text { wastes } \\
\text { disposa } \\
1\end{array}$ \\
\hline $\begin{array}{c}\text { Electricity } \\
\text { consumption } \\
\text { from external } \\
\text { sources }\end{array}$ & $\begin{array}{c}5168.4-7 \\
008 \\
t \text { of } \\
\mathrm{CO}_{2} / \text { year } \\
/ \mathrm{MW} \\
\end{array}$ & $\begin{array}{c}8.76 \\
\text { TWh/year/M } \\
\text { W }\end{array}$ & - & - & - \\
\hline $\begin{array}{c}\text { Local } \\
\text { electricity } \\
\text { generation }\end{array}$ & $\begin{array}{l}0.75 \mathrm{t} \text { of } \\
\mathrm{CO}_{2} / \mathrm{h} \\
/ \mathrm{MW}\end{array}$ & $\begin{array}{c}2.8 \\
\mathrm{MWh} / \mathrm{h} / \mathrm{MW}\end{array}$ & \begin{tabular}{|c|} 
Payment \\
included in \\
fuel excise \\
tax \\
\end{tabular} & - & - \\
\hline $\begin{array}{c}\text { One-time } \\
\text { cooling agent } \\
\text { leakage }\end{array}$ & - & - & $\begin{array}{r}<301 \\
\text { liquid/n } \\
\text { max. } 20-3 \\
\text { the substanc } \\
\text { is not com! }\end{array}$ & $\begin{array}{l}\mathrm{m}^{3} \text { of } \\
\text { nodule, } \\
0 \text { t/module, } \\
\text { e list in [12] } \\
\text { prehensive }\end{array}$ & - \\
\hline $\begin{array}{c}\text { One-time fire } \\
\text { extinguishing } \\
\text { agent } \\
\text { emission in } \\
\text { case of fire }\end{array}$ & $\begin{array}{c}<0.72 \text { t of } \\
\mathrm{CO}_{2} / \text { module }\end{array}$ & - & \begin{tabular}{|}
$>360 \mathrm{~m}^{3}$ \\
the \\
substance \\
list in [12] \\
is not \\
comprehens \\
ive
\end{tabular} & - & - \\
\hline $\begin{array}{c}\text { Electronic } \\
\text { equipment } \\
\text { wastes }\end{array}$ & $\begin{array}{c}6.8-13.5 \\
\text { t/year/modul } \\
\mathrm{e}\end{array}$ & - & - & - & $\begin{array}{c}\text { Hazard } \\
\text { class IV } \\
\text { of } \\
\text { wastes }\end{array}$ \\
\hline
\end{tabular}


Table 6. Continued.

\begin{tabular}{|c|c|c|c|c|c|}
\hline \multirow[b]{2}{*}{$\begin{array}{l}\text { Impact } \\
\text { originator }\end{array}$} & \multicolumn{5}{|c|}{ Impact magnitude } \\
\hline & $\begin{array}{l}\text { Carbon } \\
\text { footprint } \\
\text { or wastes }\end{array}$ & $\begin{array}{l}\text { Thermal } \\
\text { emission }\end{array}$ & $\begin{array}{c}\mathrm{Non} \mathrm{CO}_{2} \\
\text { emission to } \\
\text { the } \\
\text { atmosphere }\end{array}$ & $\begin{array}{c}\text { Discharge } \\
\text { to natural } \\
\text { water } \\
\text { bodies }\end{array}$ & $\begin{array}{c}\text { Solid } \\
\text { wastes } \\
\text { disposa } \\
1 \\
\end{array}$ \\
\hline $\begin{array}{l}\text { Life-expired } \\
\text { batteries }\end{array}$ & $\begin{array}{c}1.8-3.6 \\
\text { t/year/modul } \\
e\end{array}$ & - & - & - & $\begin{array}{c}\text { Hazard } \\
\text { class II } \\
\text { or III of } \\
\text { wastes }\end{array}$ \\
\hline & $\begin{array}{c}\text { No existing } \\
\text { payment } \\
\text { rates }\end{array}$ & $\begin{array}{l}\text { No existing } \\
\text { payment } \\
\text { rates }\end{array}$ & $\begin{array}{c}\text { Payment } \\
\text { rates partly } \\
\text { developed }\end{array}$ & $\begin{array}{l}\text { Payment } \\
\text { rates partly } \\
\text { developed }\end{array}$ & $\begin{array}{c}\text { Paymen } \\
\text { t rates } \\
\text { do not } \\
\text { take } \\
\text { into } \\
\text { account } \\
\text { specific } \\
\text { characte } \\
\text { r of } \\
\text { datacent } \\
\text { er } \\
\text { wastes }\end{array}$ \\
\hline
\end{tabular}

Values in Table 6 allow assessing the datacenter negative environmental impact based on certain data center power, modules quantity, the number of hours of local generation power supply and one-time cases of leakages/fires. As statistics on datacenter operation accumulate, emissions can be estimated more accurately.

\section{Conclusion}

Sustainable development requires all the datacenter environmental impacts to be quantified and controlled to create economic and other incentives to reduce datacenter effects on the biosphere. To achieve this goal it is extremely important that data centers regularly publish statistics on resource consumption of all types, indicating their sources, flow sizes in absolute form, as well as technical characteristics of the corresponding equipment.

It is necessary to develop payment rates for the carbon footprint and thermal pollution and complement the existing lists of pollutants, indicating corresponding payment rates for emissions to the atmosphere, discharge to natural water bodies, and solid wastes disposal.

\section{References}

1. E. Masanet, A. Shehabi, N. Lei, S. Smith, J. Koomey, Science, 367(6481), 984 (2020)

2. M. Koot, F. Wijnhoven, Applied Energy, 291(116798), 1 (2021)

3. A. Semenov, E. Oganesyan, Foton-Express, 2(170), 8 (2021)

4. M. Patterson (editor), D. Azevedo, C. Belady, J. Pouchet, Water Usage Effectiveness $\left(W U E^{T M}\right)$ : a Green Grid Data Center Sustainability Metric (2011)

5. C. Belady, D. Azevedo, M. Patterson, J. Pouchet, Carbon Usage Effectiveness (CUE): a Green Grid Data Center Sustainability Metric (2010)

6. C. Belady, A. Rawson, J. Pfleuger, T. Cader, Green Grid Data Center Power Efficiency Metrics: PUE and DCiE (2008) 
7. V. Avelar, D. Azevedo, A. French, H. Barrass, C. Belady et al., PUE $E^{T M}$ a Comprehensive Examination of the Metric (2012)

8. E. Oganesyan, DCJournal.ru, 9, 57 (2014)

9. E. Oganesyan, Industrial Ecology, 2(86), 77 (2014)

10. E. Oganesyan, Management in Russia and Abroad, 6, 101 (2020)

11. S. Li, Q. Zhang, Science and Pollution Research, 21, 13636 (2014)

12. Russian Federation Government Regulation \#913, 13.09.2016 "On payment rates for negative environmental impact and additional coefficients" (edition 24.01.2020)

13. A. B. Semenov, V. M. Artushenko, Lecture Notes in Electrical Engineering, 641, 1167 (2020)

14. M. Bylina, S. Glagolev, A. Semenov, R. Davydov, IEEE Int. Conf. on Electrical Engineering and Photonics (EExPolytech), 5 (2020) 